\title{
変動水圧場における護岸裏込め土砂の流出機構に関する研究 Flow-out of a Back-filling Sand behind Revetment under Cyclic Loading of Water Pressure
}

\author{
名合宏之 $*$ - 前野詩朗 $* *$ - 小谷裕司 $* * *$ - 西平福宏 $* * * *$
}

By Hiroshi NAGO, Shiro MAENO, Yuji KOTANI and Fukuhiro NISHIHIRA

\begin{abstract}
The cavity behind bank protection occurs under stormy waves and flooding. In this study, we investigated the flow-out mechanism of back-filling sand under cyclic loading of water pressure experimentally and theoretically. As a result, it is clarified that cyclic seepage force which occurs around revetment under water pressure variation plays an important role to the movement of sand around revetment and also clarified by visualization technique that the sand around revetment moves like a circular arc. Furthermore, the effect of pressure distribution behind revetment and the effect of the porosity of bed on the flow-out phenomena are examined.
\end{abstract}

Keywords : liquefaction, pore pressure, back-filling sand, water pressure variation, visualization technique

\section{1. まえがき}

洪水時における河川構造物周辺の流れや、また冬期風浪時や台風時に海岸構造物に作用する波浪は、強度 の水面変動を伴う状態にある。このような場においては、構造物周辺地盤上に絶えず変動水圧が作用するた め、地盤内に過剩間隙水圧が発生し、地盤の有効応力が時間的に変化することにより、極端な場合には地盤 が液状化することが明らかにされている1),2)。このような変動水圧場に置かれる構造物の安定性を検討する 場合には、構造物に直接作用する流体力のみならず、構造物周辺地盤の動的安定性をも考虑する必要がある

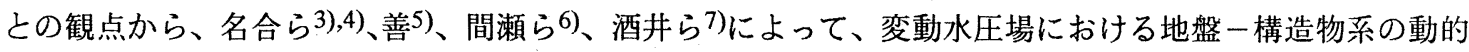
応答問題を取り扱った研究が盛んになされてきている。これらの研究により、防波堤の損壊や消波ブロック の沈下などの災害の発生機構が明らかにされつつあり、今後は、構造物周辺地盤の流動モデルを開発するこ とにより、災害の発生予測あるいは災害防止策の確立を図る必要がある。

以上のようなことを考慮して、著者らは、これまで、変動水圧場において発生すると考えられる災害の発 生形態の一つである護岸の裹込め土砂の流出に伴う空洞化に着目し、その発生機構を検討してきており、長 期の変動水圧の作用を受けて裹込め土砂が徐々に流出することやその流動機構をある程度明らかにしてきて

\begin{tabular}{|c|c|c|c|}
\hline *正会員 & 工博 & 環境理工学部環境デザイン工学科 & （テ700 岡山市津島中 2-1-1） \\
\hline **正会員 & 工博 & 環境理工学部環境デザイン工学科 & ( 同上 $)$ \\
\hline ***正会員 & 工修 & 岡山大学大学院 自然科学研究科システム科学専攻 & （同上） \\
\hline *****正会員 & 工博 & 西松建設株式会社＼cjkstart技術研究所 & （干242 大和市下鶴間 2570-4） \\
\hline
\end{tabular}


(る8),9),10)。これらの研究においては、図-1. (a)に示 すように、裹込め土砂が高飽和状態で密閉されている 状態でしかも地盤がかなり閉め固まっている状態を対 象としていた。しかし、実際の河川や海岸に設置され る護岸においては、図-1. (b)に示すように、護岸裏込 め土砂の内部には自由水面が存在し、そこでの圧力は 通常は大気压に開放されている。また、現地調査の結 果より、現地地盤がかなり緩い状態で堆積している場 合もあることが確認された11)。したがって、このよう な緩い堆積状態の地盤の挙動も把握しておく必要がある。

これらのことを考虑し、本研究においては、堤防や 護岸の裏込め土砂が大気圧に開放されている場合と密 閉されている場合ならびに地盤の間隙率を変化させた 場合の裏込め土砂の流出特性を検討するとともに、構 造物周辺地盤の流動化予測、護岸裹込め土砂流出に伴 う裏込め部の空洞化による構造物破壊の予測ならびに 空洞化防止対策工法を確立するための基礎的な資料を 得ることを目的として研究を行った。

\section{2. 実験方法}

実験には、図-2に示す幅 $80 \mathrm{~cm}$, 奥行き $30 \mathrm{~cm}$ の鉛直 2 次元砂層模型を用い、砂層構成材料は、豊浦標準砂 $\left(\mathrm{d}_{50} \fallingdotseq 0.25 \mathrm{~mm}\right.$ 、透水係数 : $\left.0.01 \mathrm{~cm} / \mathrm{s}\right)$ を用いた。また、 護岸周辺部の砂の流動を可視化するため、標準砂を高 温で焼いた着色砂（透水係数、比重 : 同一条件）を層 状に設置し、変動水压を 1000 分間作用させた後の着 色砂の移動量を計測した。

実験は、表-1に示す 4 ケースについて行った。左側 容器には鉄製護岸模型を設置し、上部は蓋を取付け密 閉できる構造としている。CASE 1 は護岸のみを設置 し大気圧に開放された条件で、CASE 2 はこれに対し 上部に蓋をして密閉された条件となっている。CASE

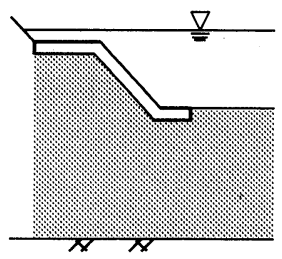

(a ) 密閉状態

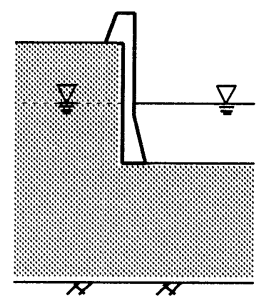

(b) 開放状態
図-1 護岸背後地の概念図

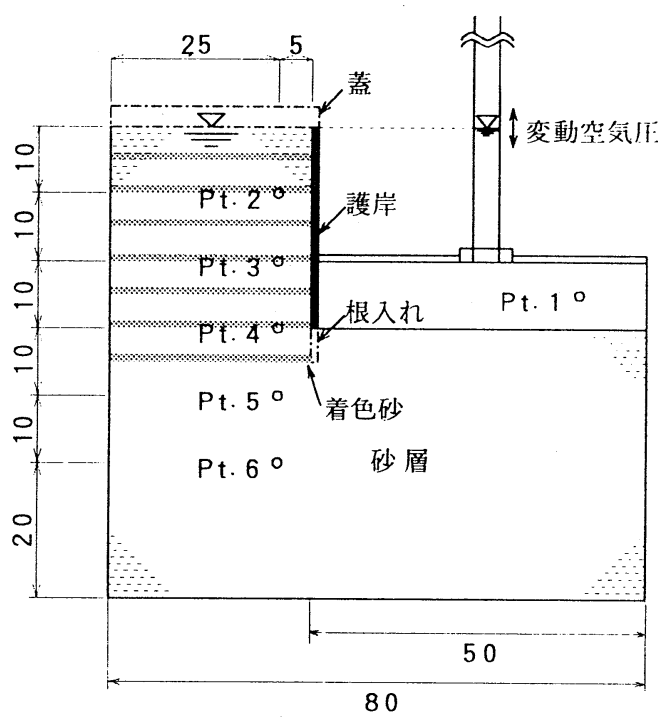

○は水压測定位置単位 : $\mathrm{c} \mathrm{m}$ )

図-2＼cjkstart実験装置の模式図

表-1 実験条件

\begin{tabular}{|c|c|c|c|}
\hline No & 間隙率 & 構 造 物 の諸 元 & 圧力状況 \\
\hline CASE 1 & 0.40 & 護岸のみ & 開放 \\
\hline CASE 2 & 0.40 & 護岸のみ & 密閉 \\
\hline CASE 3 & 0.40 & 護岸+不透水根入れ & 開放 \\
\hline CASE 4 & 0.43 & 護岸+不透水根入れ & 開放 \\
\hline
\end{tabular}

3 は、CASE 1 の装置の護岸先端に $5 \mathrm{~cm}$ の鉄製の根入 れを取付け、間隙率 0.40 と締め固まった条件にしており、CASE 4 はCASE 3 と同一の装置で間隙率を 0.43 と緩めの地盤を想定した実験条件となっている。その他の条件としては、変動水圧振幅 : $25 \mathrm{~cm}$, 周波数 : $1 \mathrm{~Hz}$ の正弦波形に近い周期的変動水圧を全ヶースに作用させている。

\section{3. 実験結果および考察}

\section{1 護岸背後地の内部圧力状況の違いによる砂の流出特性}

一般的な河川や海岸に設置された護岸は、図-1. (b)に示すように、護岸裏込め土砂の内部に地下水面が存 在し、そこでの圧力は、通常は大気圧状態で開放されている。この場合を想定した実験ケース（CASE 1） 
の裹込め土砂の流動特性を示したのが写真-1である。護岸内に設置された層状の着色砂は、長期の変動水圧 の作用を受けて流出しており、その範囲は護岸裏法面から $10 \mathrm{~cm}$ 程度であることがわかる。とくに護岸下か ら 3 層目（約 $15 \mathrm{~cm} ）$ の範囲で着色砂が護岸法先部を中心に回り込むように護岸前面に流出していることが わかる。なお、護岸鉛直下方向の流動範囲は $5 \mathrm{~cm}$ 程度以内と推定された。また、上層部の着色砂は、護岸 前面への流出は見られないものの、裏込め土砂が円弧滑り状に崩壊していることが確認された。

次に、複断面河道の低水護岸部や山裾部の海岸護岸など（図-1. (a))においては、背後地の地下水の影響 により護岸背後地は高飽和状態で密閉されている状況にある。この場合を想定した実験ケース（CASE 2） の流動特性は写真-2に示すとおりであり、CASE 1 と同様に裏込め土砂が円弧滑り状に崩壊し護岸前面に流 出している。実験終了時（1000分後）の裏込め土砂の流出量を計測した結果、図-3に示すように流出量全体 のボリュウームとしては顕著な差異は認められず、今回の実験からは護岸背後地内の内部圧力状況の違いに よる裏込め土砂の流出特性の違いは把握できなかった。

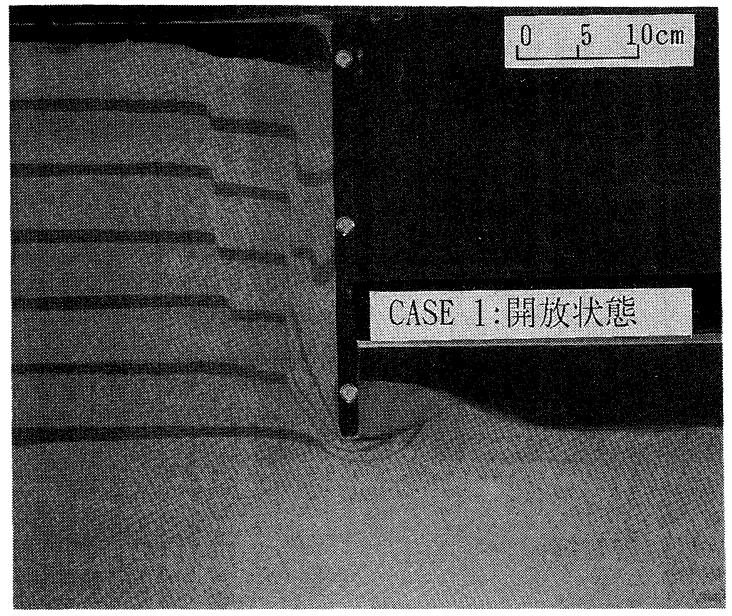

写真-1 1000 分後の流出状況（CASE 1:開放）

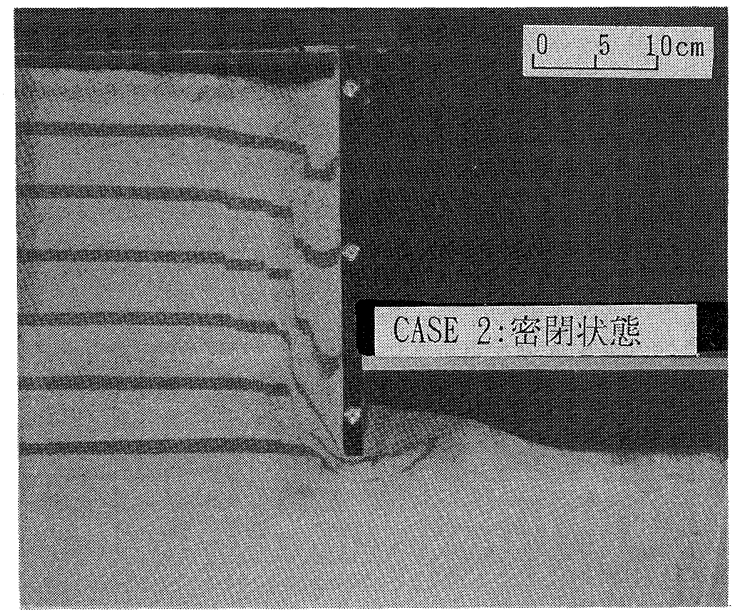

写真-2 1000 分後の流出状況 (CASE 2:密閉)

図-4および図-5は、それぞれ CASE 1 および CASE 2 の場合の実験条件を考虑して得られた等間隙水压線お よび浸透水圧の数值解析結果を示している。これらの 図は、砂首面上の変動水王が最も小さくなる時間帯を 示したものであり、裏込め土砂が最も流出しやすい状 況である。なお、浸透水压については $50\left(\mathrm{~N} / \mathrm{m}^{2}\right)$ 以上の 值についてのみ示している。

これらの図より、両ケースとも裹込め土砂を流出さ せようとする浸透水圧が発生しており、とくに、護岸 先端部において顕著となることがわかる。これは、可 視化の結果から得られた護岸先端部での土砂の移動状

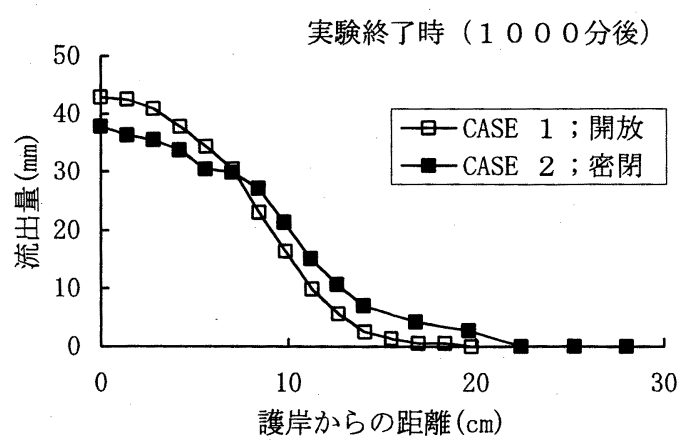

図-3 裹込め土砂の流出量 況をよく説明している。なお、護岸先端部における両者の浸透水圧の違いはほとんどないが、護岸内部にお いて CASE 1 の場合の方が浸透水圧がやや大きくなることがわかる。したがって、CASE 1 の場合の方が土 砂の流出量は多くなるはずであるが、実験で両者の流出量に変化がなかったのは以下のように説明できる。 すなわち、変動水圧場における液状化特性に大きな影響を与える位相の遅れ（dt/T : dt は位相の遅れ時間, $\mathrm{T}$ は変動水圧の周期）及び振幅減衰（Pn/P1 : Pnは各点の間隙水圧）を表した図-6に示すように、護岸内部の 
測点 Pt.2 および Pt.3では、位相の遅れについては、CASE 2 の密閉した場合の方が大きかったのに対し、振 幅については CASE 1 の開放した場合の方が大きく減衰しており、今回の実験条件下では、これらの因子の 影響が出て、両者の土砂の流出量が同程度になったものと考えられる。そこで、ここでは、密閉した場合と 開放した場合の両者の違いを明確にするために液状化特性に大きく影響を及ぼす幾つかの因子のうち、透水 係数を取り上げ、数值実験的に検討することにした。図-7は、透水係数を実験条件の約 3 倍にした場合（k $=0.03 \mathrm{~cm} / \mathrm{s}$ ）の位相の遅れと振幅減衰ならびに図-6に示した実験值とを合わせて示している。同図より、位 相の遅れについては、Pt.2では両者とも位相の遅れは少なくなっているが、減少量は CASE 2 の密閉した場 合の方が大きく、Pt.3では CASE 2 の場合は減少しているが、CASE 1 の開放している場合は変化していな いことがわかる。つぎに、振幅減衰についてみると、CASE 1 の場合はほとんど変化していないが、CASE 2 の場合には、透水係数が大きくなると振幅減衰は少なくなることがわかる。これらのことから、透水係数 が大きくなり液状化し難くなるという条件下においても、裏込め内に自由水面が存在する場合には依然とし て振幅減衰が大きくなっており、砂地盤の支持力の低下が、砂層内部に伝播する変動水圧および位相の遅れ に影響されることを考慮すると、護岸裏込め土砂の内部に自由水面が存在し大気圧状態で開放されている場 合の方が、密閉されている場合よりも裏込め土砂の流出の面からは危険側にあるもの之判断される。

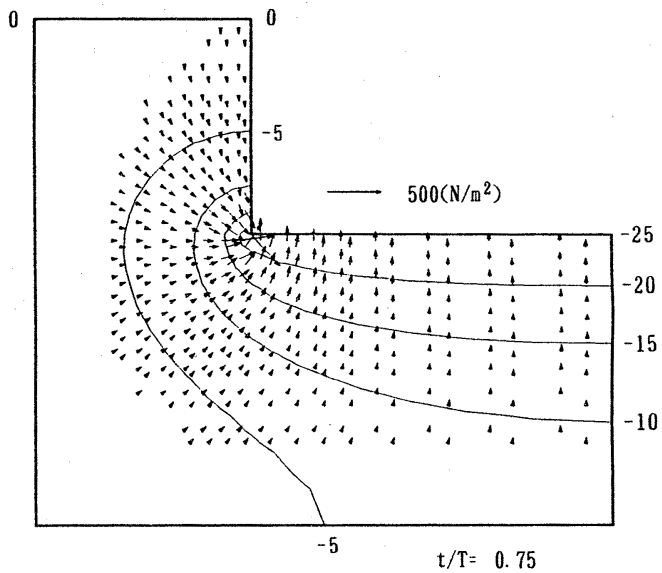

図-4 等間隙水圧および浸透水圧分布(CASE 1:開放)

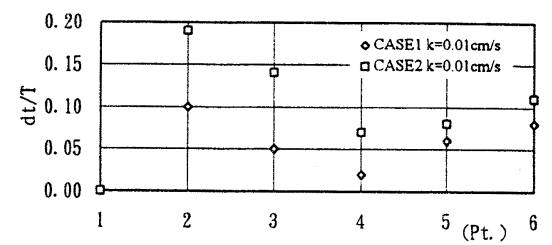

(a) 位相の荤れ

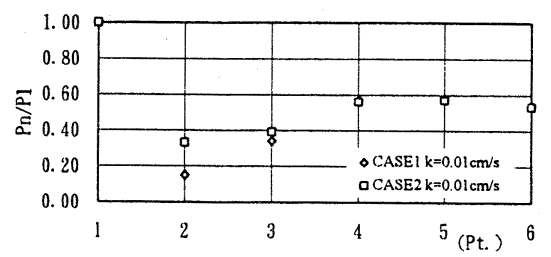

(b) 振幅の诚变

図-6 間隙水圧の位相遅れと振幅減衰(実験値)

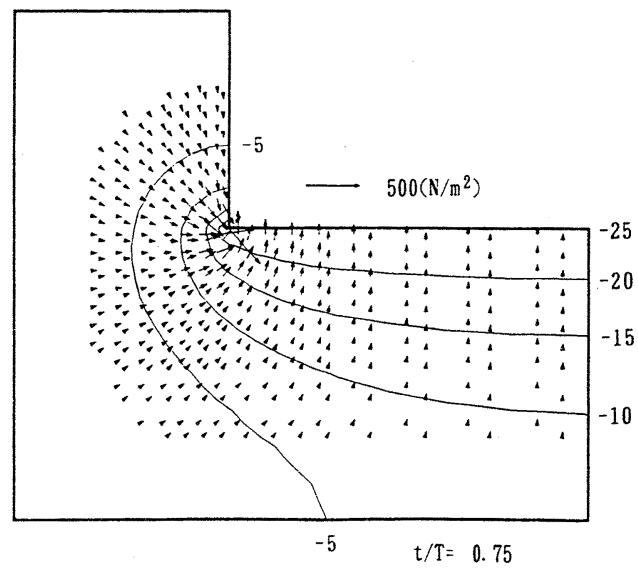

図-5 等間隙水圧および浸透水圧分布(CASE 2:密閉)

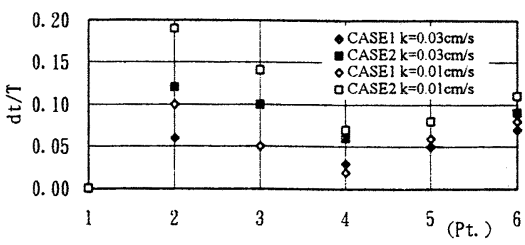

(a) 位相の䐅れ

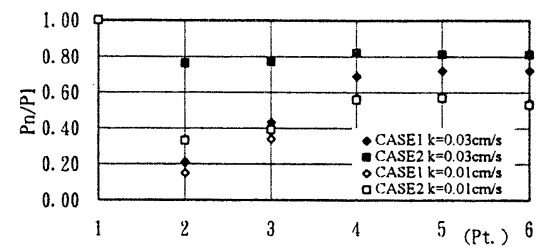

(b) 振幅の城衰

図-7 透水係数の変化による位相遅れと振幅減衰

\section{2 間隙率の違いによる砂の流出特性}

写真-3及び写真-4は、裏込め土砂の流出の影響が大きいと考えられる開放状態で、吸い出し防止対策とな 
る根入れを設置し、構造物周辺地盤の間隙率を 0.40(CASE 3)，0.43(CASE 4) と変えた場合の裏込め土砂の 流出状況を示している。なお、これらの実験で護岸先端部に取り付けた根入れ長さは、CASE 1,2 の実験結 果より、根入れ先端部での流動範囲が $5 \mathrm{~cm}$ 程度以内であったことを考慮して、 $5 \mathrm{~cm}$ としている。これらの写

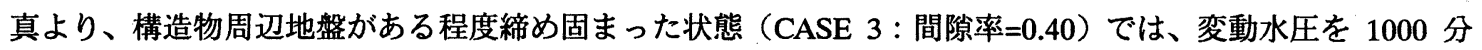
間作用させた後においても CASE 1,2 のような顕著な砂の流出は見られなく、根入れを設置すると裹込め土 砂の流出防止効果がかなりあることがわかる。しかし、写真-3に示すように、最下首の着色砂は、根入れ先 端部を回り込みつつあり、今回の実験よりもさらに長期にわたって変動水圧が作用すると、裹込め土砂が根 入れ先端部をさらに回り込んで流出が進行し、空洞化につながる可能性がある。図-8は、等間隙水压及び浸 透水圧分布の解析結果を示している。同図より、CASE 1, 2 の場合と同様に根入れ部分を回り込むように浸 透水圧が作用していることがわかる。この場合、流出量が減少したのは根入れ前面の土砂のかぶりが抑え効 果として働いたのと、土砂の流出経路が長くなったためであると考えられる。

つぎに、構造物周辺地盤が緩い状態（CASE 4 : 間隙率=0.43）においては、CASE 3 の場合よりも最下層 の着色砂がはっきりと根入れ前面部に回り込んでいる状況（写真-4）が確認された。また、実験終了時の裏 込め土砂の流出量を計測すると、図-9に示すように、裏込め土砂の流出現象がわずかながら生じていること から、この場合も、時間経過につれて裏込め部の空洞化に進展する危険性が認められた。現地での緩い堆積 状態を想定した、間隙率が 0.43 (CASE 4) の場合の方が流出量が多くなったのは、長期の変動水圧の作用に

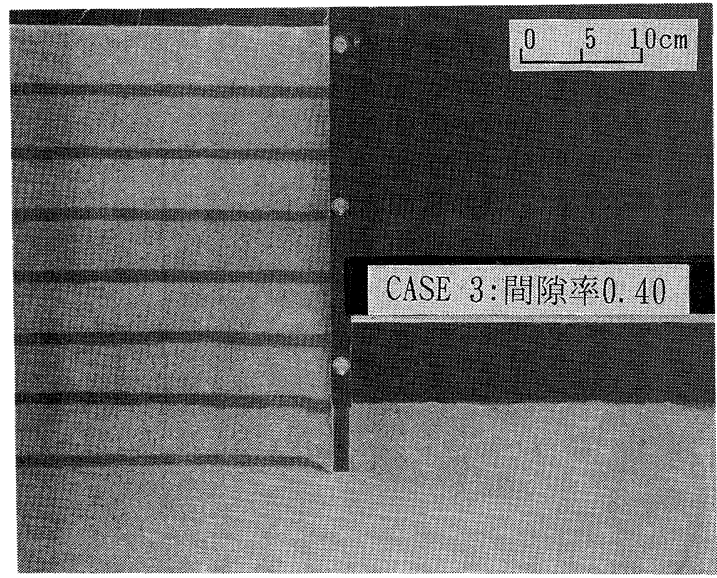

写真-3 1000 分後の流出状況（CASE 3)

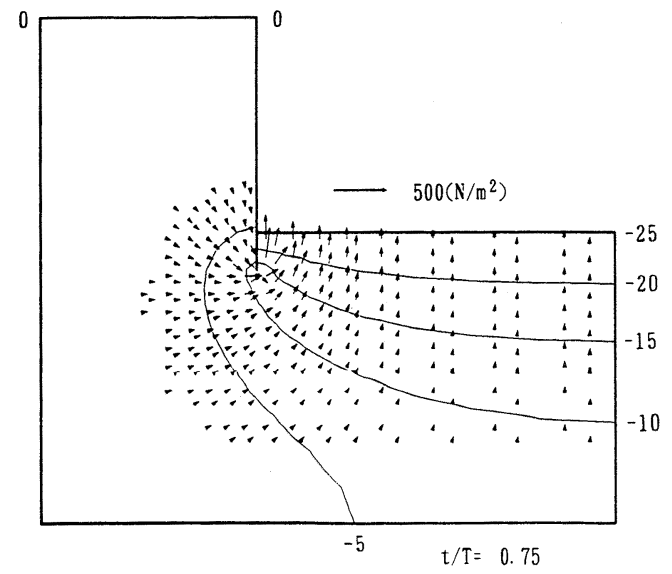

図-8 等間隙水圧および浸透水圧分布(CASE 3)

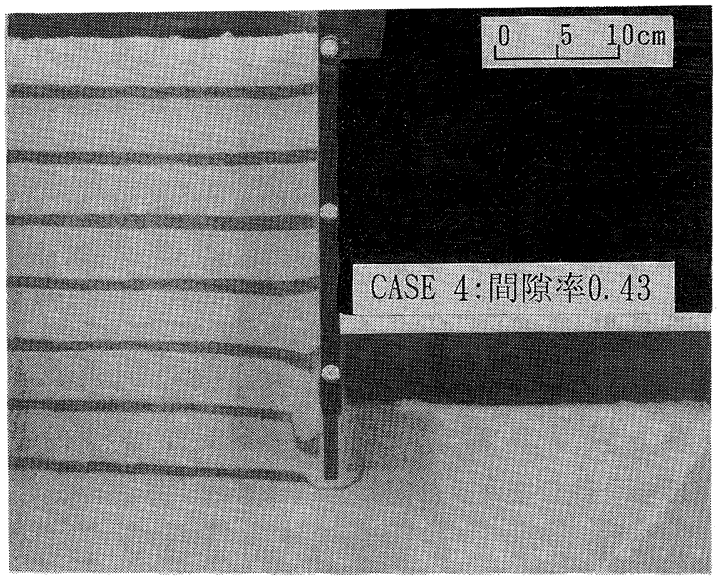

写真-4 1000 分後の流出状況（CASE 4）

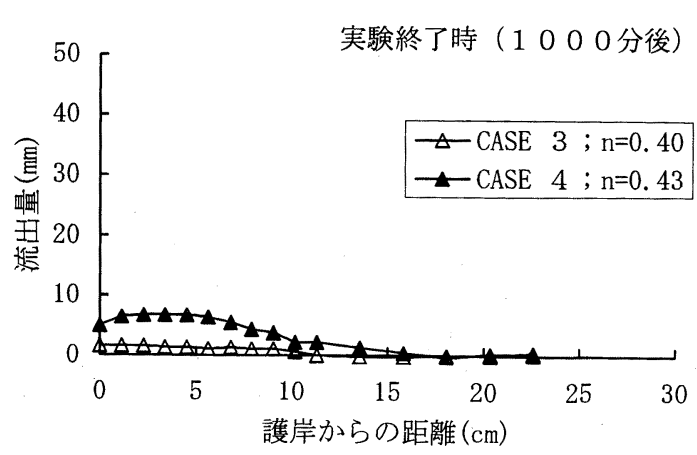

図-9 裹込め土砂の流出量(根入れ付) 
より、護岸前面の砂層において高密度化現象も同時に発生したため、地盤が締め固まっている場合 （CASE 3）よりも、裹込め土砂が流出しやすくなったためと推定される。

\section{4. 結 論}

本研究は、変動水圧場における護岸裏込め土砂の流出機構について、護岸裹込め土砂が高飽和状態で密閉 されている場合と自由水面を有し開放されている場合の裏込め土砂の流出特性の相違、および護岸周辺地盤 が緩く堆積している場合の流出特性を可視化実験ならびに数值解析により検討した。その結果、以下のよう なことを明らかにした。

（1）変動水压の作用を受け、護岸裹込め部の土砂を流出させようとする浸透水圧が長期にわたって周期的に 作用することにより、護岸裏込め土砂が円弧滑り状に崩壊し、護岸先端部を回り込むように護岸前面に流出する。

（2）裹込め部が高飽和状態で密閉されている場合と自由水面が存在し大気圧に開放されている場合について 実験を行ったが、今回の実験条件では、両者の違いは明確にできなかった。しかし、透水係数を大きくした 数值実験の結果、裹込め部が大気圧に開放されている場合の方が、流動に大きな影響を与える振幅減衰が大 きくなり、したがって、流出量も多くなる。

（3）護岸先端部に根入れを設けることにより流出量はかなり軽減される。しかし、今回の実験条件程度の根 入れ長においては、根入れ先端部では若干ではあるが土砂の流動がみられ、長期的には護岸裹込め部の空洞 化につながる可能性がある。

（4）地盤が緩く堆積している場合には、地盤の高密度化も同時に発生し、地盤が締め固まった場合よりも流 出しやすく空洞化の危険性が大きいことが示された。

以上のように、本研究の結果、護岸裏込め土砂の移動状況や周辺地盤の間隙率の相違による裏込め土砂の 流出特性が明らかにされた。今後は、本研究で得られた成果をもとに、変動水圧場における構造物周辺地盤 の流動化予測モデルの確立ならびに裹込め土砂の流出による護岸背後の空洞化防止対策工法について、さら に検討していく必要がある。

謝 辞 : 本研究を遂行するにあたっては、岡山大学大学院山本哲雄君および同大学水工学研究室市川隆也君 の協力を得た。また、文部省科学研究費国際共同研究（代表者 岡山大学名合宏之教授、No.04044121）の 補助を受けたことを付記し、謝意を表する。

\section{参考文献}

1）名合宏之 : 変動水圧による砂層の液状化に関する研究, 水理講演会論文集, 第26巻, pp.589-594,1982.

2) Nago, H. and Maeno, S. : Pore pressure and effective stress in a highly saturated sand bed under water pressure variation on its surface, Natural Disaster Science, Vol.9, No.1, pp.23-35, 1987.

3) Maeno, S. and Nago, H. : Numerical analysis on the dynamic behavior of sea bed around break-water, GEO-COAST'91, pp.591-595, 1991.

4) 名合宏之・前野詩朗・清水雄一 : 変動水圧によるブロックの沈下にともなう周辺砂地盤の流動の可視化, 海岸工学 論文集, 第40巻, pp.516-520, 1993.

5）善 功企 : 海洋開発における波之海底地盤の動的問題, 昭和59年度港湾技術研究所講演会講演集, pp.77-133, 1984.

6）間瀬肇・酒井哲郎・西村喜弘・前野賀彦：多孔質弾性体理論による防波堤に作用する揚圧力および周辺地盤内の 変動間隙水圧の解析, 土木学会論文集, 第411号 II -12,pp.217-225, 1988.

7）酒井哲郎・間瀬肇・山本哲也：水圧変動による地盤表面付近の間隙水圧変動, 海岸工学論文集, 第40巻, pp:586-590, 1993.

8）名合宏之・前野詩朗 : 変動水圧作用下における護岸の裏込め土砂の吸い出しに関する研究, 水理講演会論文集, 第 32巻, pp.595-600, 1988.

9) Nago, H. and Maeno, S. : Movement of sand around revetment under water pressure variation, Memoirs of Faculty of Engineering, Okayama Univ., Vol.24, No.2, pp.67-78, 1990.

10) Nago, H., Maeno, S. and Shimizu,Y. : Visualization of the movement of back-filling sand under the cyclic loading of water pressure, IAHR, pp.248-253, 1993.

11）松本高之: 変動水圧による砂地盤の動的挙動に関する研究, 岡山大学修士論文, pp.77-114, 1994. 